水文・水筫源学会誌 J. Japan Soc. Hydrol. \& Water Resour. Vol. 7. No. 6 (1994) pp. $520-528$

\title{
チャオプラヤ流域の水資源危機とその対策
}

\section{Counter-Measures Against Water Resources Crisis in the Chao Phraya River Basin}

\section{新谷 渡* \\ Wataru SHINTANI \\ 竹内邦良**}

Kuniyoshi TAKEUCHI

ヴァンチャイ

Vanchai SIVAARTHITKUL

\author{
（山梨大学大学院）
}

Graduate Student, Yamanashi University

(山梨大学工学部)

Faculty of Engineering, Yamanashi University

(山梨大学大学院)

Graduate Student, Yamanashi University

There are two large reservoirs in the Chao Phraya River Basin, namely, the Bhumibol and the Sirikit. The Storage volume is 13.5 and $9.5\left[\times 10^{9} \mathrm{~m}^{3}\right]$, respectively. Up to 1980 , the priority was given to hydro-power generation and nowadays to paddy field irrigation of the Chao Phraya Delta. Water crisis in the Chao Phraya River Basin have been occurring continuously in 1990's and water storage levels of both reservoirs are low. The main reasons are the decrease of inflows and the increase of consumption disobeying the planned operation rule. To solve the problem, we introduce, apart from the measures that Thai Government is taking, the rule that restricts irrigation area according to reservoir storage available at the beginning of cropping season.

Key words : water resources crisis, dry season irrigation area, Chao Phraya Delta, Bhumibol Reservoir, Sirikit Reservoir

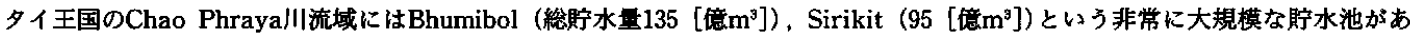
る.この貯水池は, 以前は発電を, 現在はその下流にあるChao Phraya川流域の耕作地帯への潅溉用水供給を主な目的として放流操 作されている. 近年の両貯水池の貯水量は低下の一途をたどり，90年代は死水域寸前の状況にあり，大きな問題となっている.この 原因については, 近年貯水池への流入量が減ってきていることや, 耕作面積の大きさに伴う潅激用水の供給量等が挙げられる.その 対策として現在タイ王国で提案されているいくつかの計画, ならびに我々が考莱したルールについて紹介する.このルールはこれか

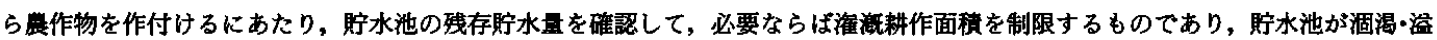
水する危険率をパラメータとして表わしてある，このルールから近年の潅酹耕作面積はかなり危険率の高い状況であったことが浮 き㰹りとなった。

キーワード：水資源危機，乾期潅溉耕作面積，チャオプラヤ・デルタ，プミボン・ダム，シリキット・ダム

\section{I .はじめに}

\section{Chao Phraya流城}

図一 1 にタイ王国のChao Phraya川流域図を示す。 流域面積は約 $16\left[\right.$ 万 $\left.\mathrm{km}^{2}\right]$ で国土の約 30 [\%] を占め
ている. 上流にはPing, Wang, Yom, Nanと 4 つ の支川があり, Nakhon Sawan県で合流してChao Phraya川となる. Chao Phraya川デルタは, 河口か ら約200 [km] 上流のChai Natを頂点に, シャム湾 に面した海岸線を底辺とした三角形の形をとってい

*山梨大学大学院博士後期課程 $\bar{T} 400$ 山梨県甲时市武田4-3-11, Tel: 0552-20-8603, Fax: 0552-53-4915

Doctor's Course, Graduate Student, Yamanashi University, Dept. Civil and Environmental Eng., Faculty of Eng., Yamanashi Univ., Takeda-4, Kofu, 400, Japan

**山梨大学工学部土木謤境工学科 Dept. Civil and Environmental Eng., Yamanashi University 


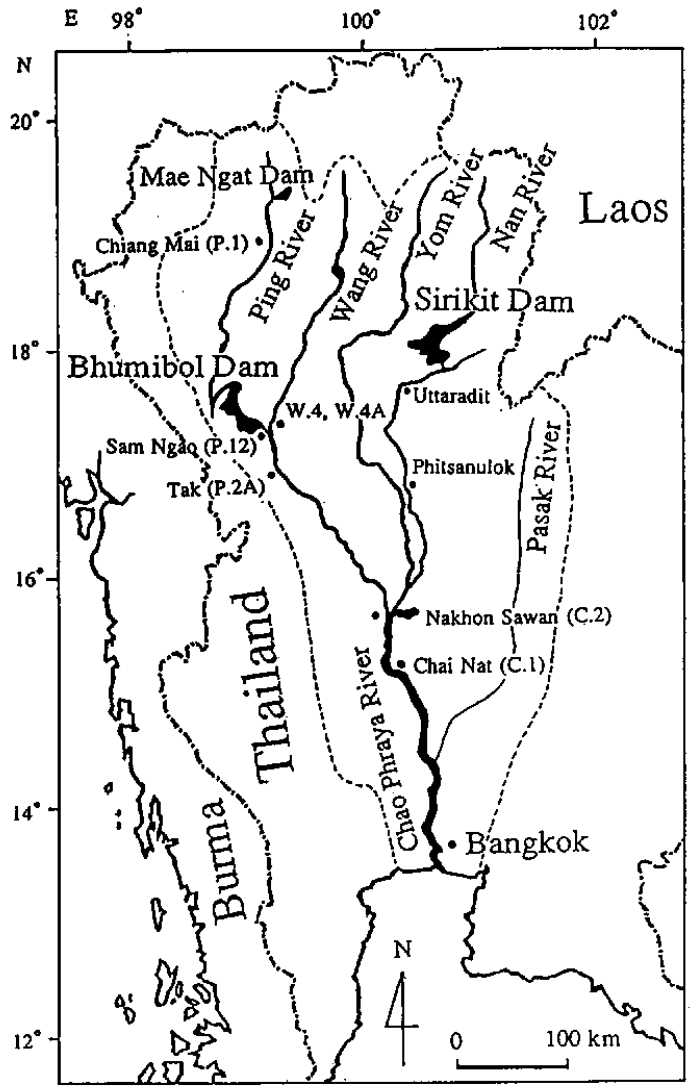

Figure 1 Chao Phraya Basin
る.ここに広大な水田地帯が広がっており，世界有 数の米作地帯となっている，その上流にはBhumibol, Sirikitという大規模貯水池があり，この地域の 産業，経済に多大な恩恵を与えている，表一1に両 貯水池の概要を示す (EGAT, 1989).

例年Chao Phrayaデルタでは二期作が行われてい る.この流域は熱帯サバナ気候に属しており, 雨期 は耕作地帯への直接降雨及び両貯水池を経由せずに 流出する河川流量 (残留域流出)を利用して主に稲作 を行い, その両者で足りない分は両貯水池から補給 する. 乾期は降雨, 残留域流出があまりないため, 潅溉用水のほとんどをBhumibol, Sirikit両貯水池 から供給している. '81年以降の乾期の耕作面積は例 年約 $4,800\left[\mathrm{~km}^{2}\right](3,000,000[\mathrm{rai}])$, 雨期 は約

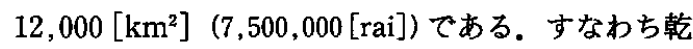
期の潅溉耕作面積は, Chao Phrayaデルタの耕作地 帯の面積の40［\%] である (Takeuchi, 1993; Sribhibhadh et al ., 1988; Kerdpitak et al ., 1987; Panichpong et al., 1987).

\section{2. 眝水池からの放流目的の变移}

図一 2 にBhumibolの月流入量と月放流量の経年 図を示す.Bhumibol Damは1964年に完成し，当初 は発電を主目的に放流を行っていた，1972年にSirikit Damが完成し，この時に放流の主目的を潅溉用 水供給と発電の両方にとったことにより，乾期にゃ

Table 1 Characteristics of Bhumibol and Sirikit Reservoir

\begin{tabular}{|l|c|c|c|c|l|}
\hline Name of Dam & $\begin{array}{l}\text { Catchment Area } \\
{\left[\mathrm{km}^{2}\right]}\end{array}$ & $\begin{array}{l}\text { Average Inflow } \\
(1952-91)\left[\mathrm{m}^{3} / \mathrm{s}\right]\end{array}$ & $\begin{array}{l}\text { Effective Storage } \\
{\left[\times 10^{6} \mathrm{~m}^{3}\right]}\end{array}$ & $\begin{array}{l}\text { Mean Residential } \\
\text { Time [year] }\end{array}$ & $\begin{array}{l}\text { Installed Power } \\
\text { Capacity [MW] }\end{array}$ \\
\hline Bhumibol Dam & 26,400 & 186 & 9,662 & 1.6 & $6 \times 70+1 \times 115=535$ \\
\hline Sirikit Dam & 13,300 & 175 & 6,660 & 1.2 & $3 \times 125=375$ \\
\hline
\end{tabular}

[x10 $\left.\mathrm{m}^{\prime}\right]$

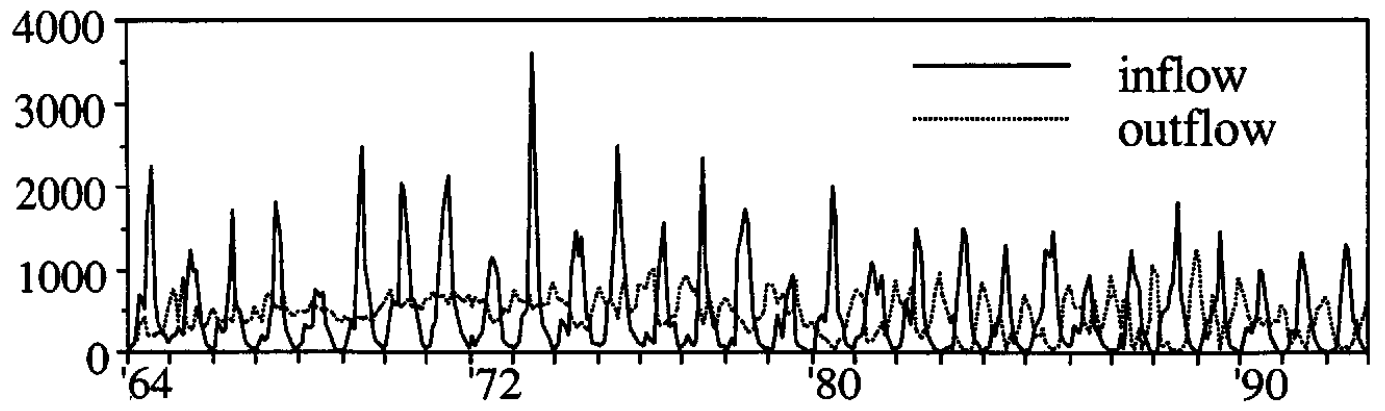

Figure 2 Monthly Inflow and Outflow of Bhumibol Reservoir 
や多く，雨期をやや抑制した放流をするというパ ターンに変わった。これを契機に農民は, 乾期でも 耕作が可能だということがわかり，70年代は乾期の 耕作面積が年々増加していった。'79年の時点では, 乾期の耕作面積は’73年頃の約 4 倍にも拡大してい た (Siriwadh, 1989).

'79年は大渴水年だったため，それに伴う雨期の潅 溉用水補給量も大きく, その結果' 80 年の乾期の耕作 のための潅溉用水が不足し, 大きな社会問題となっ た。これを契機に'80年以降は，放流の主目的を潅溉 用水供給とし，発電は副次的利用の方針をとるよう になった。これにより放流の殆どは乾期に行われる ようになり，雨期の放流はかなり抑えられている. よって図一 2 に示された流入量と放流量の関係は, かなり正確に半年フェーズのずれた互い違いの関係 になっている.

\section{II. 両貯水池の水位低下の現状とその原因}

\section{1. 水位变勤の特徽，踷景及ひ影策}

图一 3 はBhumibol, Sirikit両貯水池合計の貯水 量変動を示したものである.満水位 (上端の横線), 死 水域 (下端の横線), Upper及びLower Rule Curveも 両貯水池合計のものである. Upper Rule Curveは洪 水時に備えて空けておくべき限界水位を示したもの である. Lower Rule Curveは, 貯水量がこれを下 回った場合は, 下流での需要に対してその放流の一 部を制限する境界水位として決められている（Sib- hibhadh et al., 1988; Rohde et al., 1981).

毎年の貯水量変動の特徴として，1月から 5 月の 乾期の耕作期間中は，流入がほとんど無く，例年は およそ4,800 $\left[\mathrm{km}^{2}\right]$ の耕作地帯に潅泊用水を供給す るので, 図一3に示すようなパターンで水位を下げ て行く，6月から始まる雨期の耕作期間は，流入が 増えてくるため,この期間に水位を大きく取り戻し ている.

'86年の貯水量はかなり高いところにあったが, 年々水位の低下を招き, '91, '92年に至っては死水域 に達する寸前の状況にある．このため発電が満足に できないことや, 耕作地帯へ安定した水供給ができ ないこと，海水の遡上を抑えるための河川維持流量 が確保できなかったため, 果樹園や畑では塩害がで たり, Bangkokでは水道水に塩水が混ざるといった 事態も起こっている.

\section{2. 眝水吾低下及ひ涸渴の原因}

この貯水量低下及び涸晹の原因としては, 次に述 べるa）からd）が考えられる。

a) Lower Rule Curveが守られていない

貯水量がLower Rule Curveを下回ったときには, 放流を制限して貯水池が涸渴してしまうことを避け るようにする必要がある，しかし, 貯水池からの放 流の主目的が潅溉用水供給であるため, 耕作期間中 に水供給を削減することは, 農作物の育成に直接影 響を与えるために，現実には実行困難である.

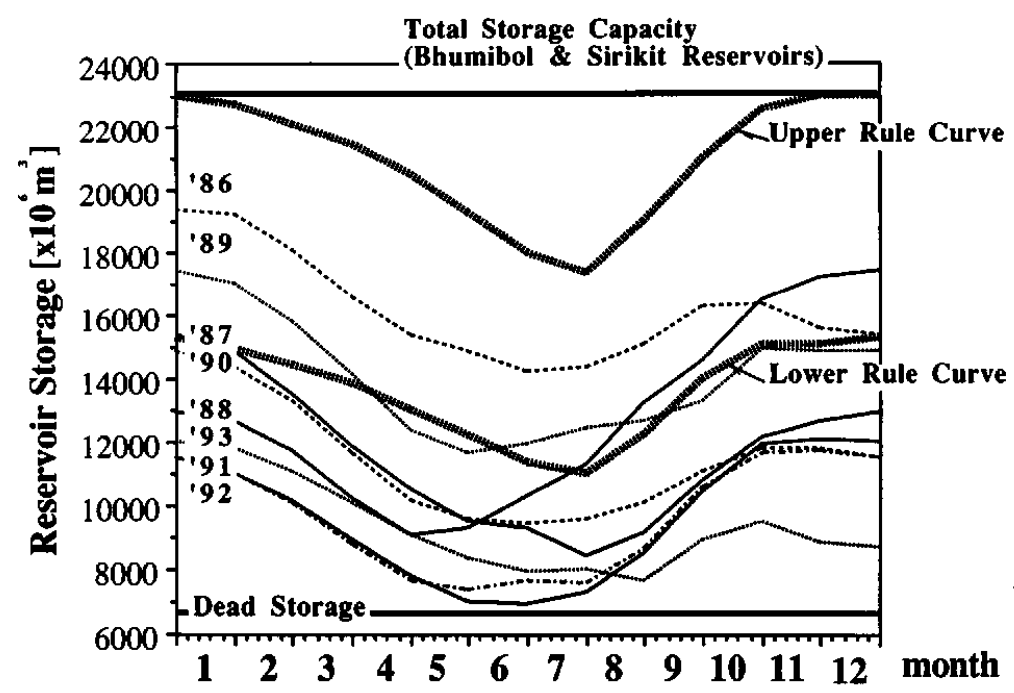

Figure 3 Temporal Changes of Total Reservoir Storage (Bhumibol and Sirikit Reservoirs) 


\section{b）無効放流}

貯水池から水田地带までおおよそ500 [km] 離れ ているために, ダムから放流した水が耕作地帯に達 するまでに数日間かかる.この期間の気象予測が完 全にはできないために，潅溉用水が降雨中の水田に 供給されるなどの無効放流は必ず生じる.

c）乾期作のための準橵貯水量が少ないときの，潅

\section{溉用水供給量}

図一 3 の'90年代の水位変動の中で頻繁に見られ るように, 乾期の耕作期が始まる時点ですでに両貯 水池の残存貯水量が少ないときは, 予め乾期の耕作 面積を制限して，潅溉用水供給量を抑えることによ り，貯水池が涸渴してしまうことを避ける必要があ る.しかし実際には, 貯水量が少ないにも関わらず, 広く作付が行われていた。 (IV章 3 節及び图一9参照)

\section{d）貯水池への流入量の減少}

图一 4 はBhumibol貯水池上流域Chiang Mai県て の年降雨高及びBhumibol貯水池への年流入高の経 年図, 図一 5 はSirikit貯水池.上流域Nan県での年降 雨高及びSirikit貯水池への年流入高の経年図, 図 -6 はBhumibol貯水池上流のPing川流域での耕作 面積の経年図である，衰一 2 は図一 $4 ， 5$ で示され た回㷌直線の傾きとその期間における平均値をまと めてある. 1972-91年の 20 年間及び1952-91年の 40 年 間の傾向をみると, いずれの貯水池への流入量も隇 少傾向にあることがわかる，量的には両貯水池への $1972-91$ 年の 20 年平均の年流入量は $108\left[\right.$ 億 $\mathrm{m}^{3} /$ 年 $]$ で あるが，1987-91年の 5 年平均では $84\left[\right.$ 億 $\mathrm{m}^{3} /$ 年 $]$ で あり, 流入量の約 20 [\%] 減の状態が継続している ことがわかる。これは上流域の降雨 (Sirikitでの 1952-91年は除く）そのものが減少傾向にあることや， Ping川上流域におけるMae Ngat Dam（'85年竣工， 総貯水量2.65[巵 $\left.\mathbf{m}^{3}\right]$ ), Mae Kuang Dam ('93年, $2.63\left[\right.$ 億 $\left.\left.\mathrm{m}^{3}\right]\right)$ 等の建設に伴うこの地域での水消費量 の増加等が原因と考えられている (Peetanonchai,

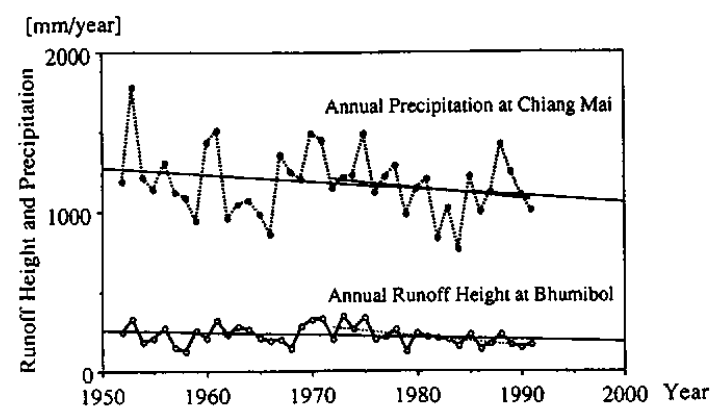

Figure 4 Annual Precipitation at Chiang Mai and Annual Runoff Height at Bhumibol Dam

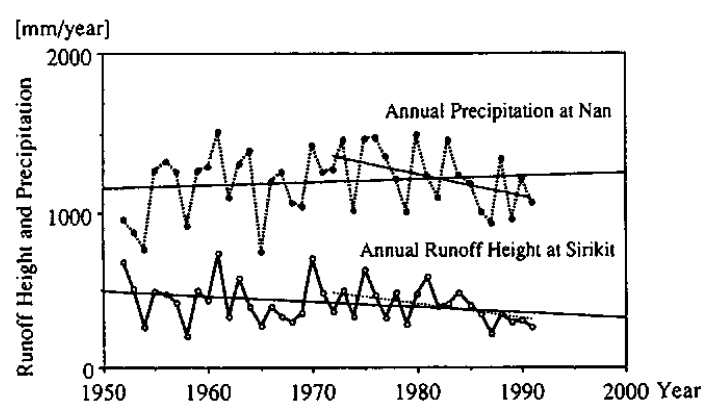

Figure 5 Annual Precipitation at Nan and Annual Runoff Height at Sirikit Dam

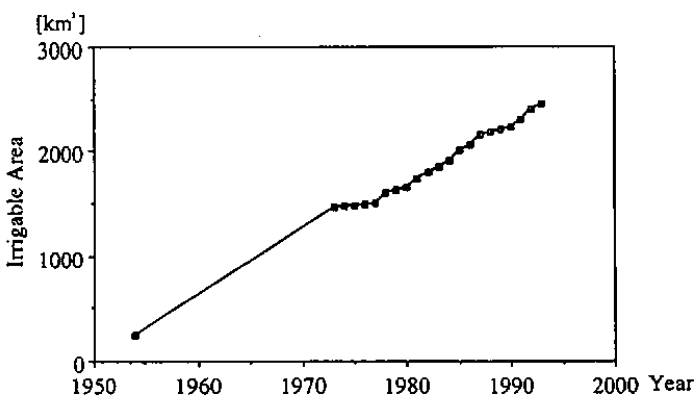

Figure 6 Development of Irrigable Area in the Upper Ping Basin

Table 2 Summary of Hydro-Meteorological Information of Bhumibol and Sirikit Catchments

\begin{tabular}{|c|c|c|c|c|c|c|c|c|c|}
\hline \multirow{3}{*}{ Station } & \multicolumn{4}{|c|}{ Precipitation [mm/year] } & \multirow{3}{*}{ Station } & \multicolumn{4}{|c|}{ Runoff Height [mm/year] } \\
\hline & \multicolumn{2}{|c|}{ 1972-91 (20 year) } & \multicolumn{2}{|c|}{$1952-91$ (40 year) } & & \multicolumn{2}{|c|}{ 1972-91 (20 year) } & \multicolumn{2}{|c|}{ 1952-91 (40 year) } \\
\hline & Mean & Trend & Mean & Trend & & Mean & Trend & Mean & Trend \\
\hline Chiang Mai & 1143.97 & -7.22 & 1179.68 & -4.12 & Bhumibol & 209.82 & -6.09 & 221.6 & -1.55 \\
\hline Nan & 1231.34 & -14.4 & 1195.19 & +1.90 & Sirikit & 395.74 & -9.16 & 415.8 & -3.32 \\
\hline
\end{tabular}


1993).

III. 対 策

1. 流域内にさらにダムを建設する

2. 灌国を含む他流城から竞水する

1,2 に関しての計画を图一 7 と表一 3 に示す. これらの計画は主に夕イ国電力省 (EGAT) を中心に 進められており，経済的，技術的，環境への影響， そして水資源開発すへての側面から調查し，可能な 選択肢を検討している.（2）功ら（7)の計画は，夕 イ国内を流れる河川から䇟国ビルマを流れるSalawin川へ流出してしまうものをBhumibolへ送水す る構想である。（8)から(10)は同様に隣国ラオスと の国境を流れるMae Khongへ流出するものをSirikitへ送水するものである.（1）はビルマの領地にダ ムを建設し, 国際河川のSalawin川から年間100 [億 $\mathrm{m}^{\mathrm{s}} \mathrm{z}$ もの水を分流しようとするもので, これの実現 はかなり難しいものと思われる (Mahasandana, 1989).

\section{3. 稻作から野菜や果樹栽培への転作の指茅}

政府は稲作の代りに，稲よりも水をあまり消費し ない野菜や果樹栽培をするように指導している.し かしながら農民としては, 土地を改良するための初 期投資が必要であること，野菜は失敗するときもあ り米の方が作り易いこと, 米以外の農作物の育成に あまり精通していない等の理由て，稲作が賢明な選 択となっている．また果樹栽培に関して言えば，市 場の価格は良いが，年間通じての水の安定供給が必 要である. しかし水利権といったものが確立してい ないので，乾期に水が到達しない所もでてくる。こ の時のダメージは稲作より大きいため，大きなリス クを伴う転作に踣躇する地域もある (Kono, 1993).

\section{4. 無効放流を少なくする}

無効放流を減らす方法としては, 水田地帯のやや 上流のNakhon Sawan地点での流量予測をするこ と(国際協力事業団, 1988), 耕作地帯もしくはその上 流に調整池を設ける等が考えられる。これらは短期 的な時間スケールでのモデルの構築が必要となって くる.

\section{5. 乾期の洦貺耕作面稘を制限する}

乾期の耕作期が始まる時点ですでに両貯水池の残 存貯水量が少ないときは, 予め乾期の潅溉耕作面積

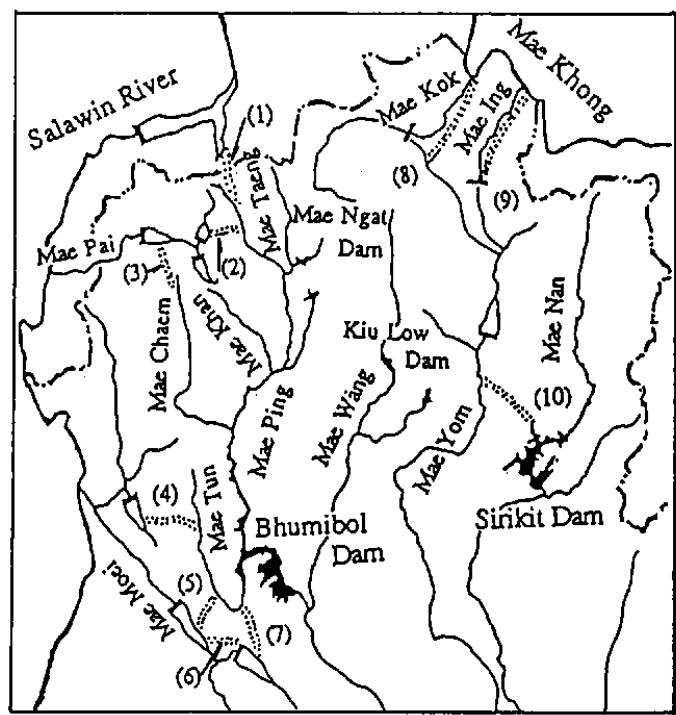

Figure 7 Proposed Water Diversion Projects

Table 3 Proposed Water Diversion Projects

\begin{tabular}{|l|c|}
\hline \multicolumn{1}{|c|}{ planning project } & $\begin{array}{l}\text { planning water } \\
\text { transportation } \\
{\left[\times 10^{\circ} \mathrm{m}^{3} / \text { year }\right]}\end{array}$ \\
\hline (1) Salawin Rever - Mae Taeng & 10,000 \\
\hline (2) Mae Pai - Mae Khan & $300-500$ \\
\hline (3) Mae Pai - Mae Chaem & 500 \\
\hline (4) Mae Ngao - Mae Tun & 500 \\
\hline (5) Mae Moei - Mae Tun & 500 \\
\hline (6) Mae Cha Rao - Mae Tun & 500 \\
\hline (7) Mae Lamao - Mae Tun & 500 \\
\hline (8) Mae Kok - Mae Yom & \\
\hline (9) Mae Ing - Mae Yom & $(8),(9),(10) \ldots$ \\
\hline (10) Mae Yom - Sirikit Reservoir & 1500 \\
\hline
\end{tabular}

を制限する。このことに関して，どこまで制限すれ ばよいか，その定量的なガイドラインが現実には必 要になってくる.

\section{IV. 乾期潅溉耕作面䖽制約モデルと部算結果}

上述の諸対策のうち, 本論文ではIII章 5 節の乾期 の潅穊耕作面䅡を制限する為の, 合理的なルール作 りを検討した.このルールは, 雨期の耕作面積を $12,000\left[\mathrm{~km}^{2}\right]$ 一定と考え, 乾期の耕作面積を与える ルールである。つまり乾期耕作期の始まりの時点で, 


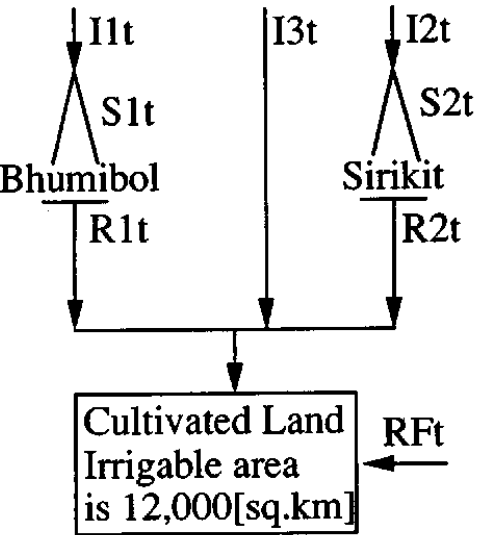

Figure 8 Schematic Diagram

両貯水池の残存貯水量（乾期耕作準備貯水量）が少な い時には, それに応じて乾期の耕作面積を減らして 潅溉用水供給量を抑えて, 貯水池が任意の確率で涸 渴・溢水するという事態を避けるという考え方を用 いる. なお塩水遡上阻止や河川航行の為の河川維持 用水及びBangkok地域での上水量等は, 一切制限せ ずすずて供給するものとした．以下にモデルを述 ベる.

\section{Chance Constraint DDC $\cdot$ FDC Model}

既存の流域をモデル用に模式化したものを図一8 に示す. 乾期潅筑耕作面積を $A(C)$ とし, そのときの 耕作面積制限率を $C$ として表すと次のようになる.

$$
A(C)=(1-C) \cdot 4,800\left[\mathrm{~km}^{2}\right]
$$

この $C$ を時刻 $\tau=1$ [半旬] ( 1 月第 1 半旬) 加ら乾期 の耕作期間中ずっと続けて，なお且つその後に続く 雨期の間の潅溉用水を必要量すべて供給した場合で も, 貯水池が涸渴する確率を $\beta$ 以下, 溢水する確率を $\alpha$ 以下に保たれるようにするために, $\tau$ 時点で必要な 両貯水池合計貯水量 $V$ の最小值 $G$ ，以下の確率制 約条件を満たす解として求められる（竹内·新谷, 1993; 竹内他, 1984; Takeuchi, 1986).

$$
G(\tau, C, \beta, \alpha)=\operatorname{minimum} V
$$

subject to

$$
\begin{gathered}
S \tau+m=S \tau+m-1+I \tau+m-1 \\
-R \tau+m-1-P \tau+m-1
\end{gathered}
$$

Prob $\{S \tau+m \leqq 0\} \leqq \beta$

Prob $\{S \tau+m \geqq V c a p\} \leqq \alpha$

$R \tau+m-1=(1-C) \cdot D I \tau+m+1+D S \tau+m+1-$

$$
(1-C) \cdot A \max (m) \cdot R F \tau+m+1-I 3 \tau+m
$$

$$
\begin{aligned}
& S \tau=V \\
& R \tau+m \geqq 0
\end{aligned}
$$

$$
m=1,2, \cdots, 73
$$

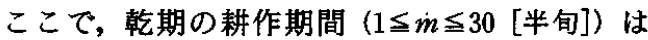
$A \max (m)=4,800\left[\mathrm{~km}^{2}\right]$ の面積に対し, $0 \leqq C \leqq 1 の$ 範囲で作付区域の制限を行う。

雨期の耕作期間 $(31 \leqq m \leqq 73[$ 半旬] $)$ は $A$ max $(m)=$ $12,000\left[\mathrm{~km}^{2}\right]$ に対して作付区域の制限は一切行わな いものとする $(C=0)$.

$$
\tau+m-1 \text { : 現時点 } \tau \text { 半旬より } m \text { 半旬後の時点. }
$$

$R t \quad(=R 1 t+R 2 t)$, It $\quad(=I 1 t+I 2 t), P t \quad(=P 1 t+$ $P 2 t): 1 t$ 時点でのBhumibol及びSirikit両貯水池に おける合計放流量, 合計流入量, 合計蒸発量.

$S t(=S 1 t+S 2 t): t$ 時点期首でのBhumibol及び Sirikit両貯水池における合計貯水量.

$R 1 t, R 2 t: t$ 時点におけるBhumibol, Sirikit貯 水池からの放流量.

$I 1 t, I 2 t: t$ 時点におけるBhumibol, Sirikit貯水 池への流入量.

$P 1 t, P 2 t: t$ 時点におけるBhumibol, Sirikit貯 水池からの蒸発量.

$S 1 t, S 2 t: t$ 時点期首におけるBhumibol, Sirikit 貯水池の貯水量.

$I 3 t: t$ 時点におけるBhumibol及びSirikit両貯水 池を経由せずに流出する河川流量 (残留域流出).

$R F t: t$ 時点におけるチャオプラャ・デルタ内の降 雨観測所51地点の平均降雨量.

DIt $: A \max (m)$ 耕作した際のt時点における耕作 地帯での推定水需要量.

$D S t: t$ 時点における上水, 塩水遡上防止及び舟運 の為の河川維持用水等の需要量.

$V c a p$ : 両貯水池合計の貯水池容量.

$C$ : 乾期潅溉耕作面積制限率.

$\beta$ : 涸渴危険率.

$\alpha:$ 溢水危険率.

また $I 1 t, I 2 t, I 3 t, R F t$ に関しては，1972-89年 の半旬データをDDC・FDCという形で統計処理した ものを用いた（吉川・竹内, 1975; RID, 1912-88).

\section{2. 潠水・涸渴危険率 $\alpha, \beta$ について}

\section{a) 湓水危険率 $\alpha$}

ここでいう溢水とは両貯水池が同時に湓水してし まうことを指す．よって溢水時期が同時になるよう な操作をすることを前提としている，この貯水池で は流入量に対する貯水池容量が非常に大きいので， 


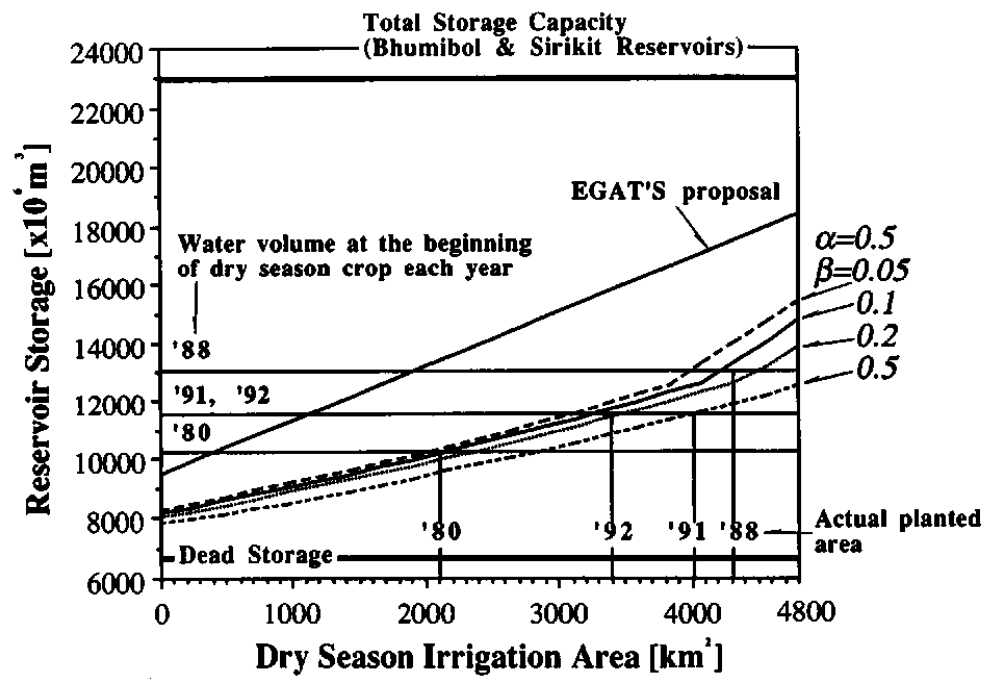

Figure 9 DDC-FDC Irrigation Area Planning Curve

水位が低い時は溢水する可能性は極めて低いため $\alpha$ の値は変えてもかなり小さい值でない限りルールの 形は全く変わらない．貯水池容量が小さい場合は, この $\alpha$ の値をどうするかも考虑に入れる必要がある. ここでは0.5という值を用いたが溢水してしまう危 険率は実際にはもっと低いものとなっている.

\section{b) 涸浔危除率 $\beta$}

$\beta$ は $0.05,0.1,0.2,0.5$ と 4 通りの涸渴危険率を 用いてここでは計算した。どのくらいの涸渴危険率 に対処できるように潅溉面積を決めるか，つまり $\beta$ の值をどうするかは，政策的な判断の下であらかじ め決めておく必要がある。

\section{3. 得られた結果の検时}

图一9は $A(C)$ とGの関係を示したものである. このルール (DDC·FDC Irrigation Area Planning Curve) は，乾期の耕作を始める時点(この流域の場合 は年初)で両貯水池における総貯水量を確認し，それ を基に乾期の潅溉耕作面稓を決めるというものであ る.

\section{a）現実の作付状況とその危険率}

'91, '92年の年初の貯水量は約 115 [億的] であっ たが,例えば0.1の涸渴危険率で耕作面積を決める場 合は約 $3,200\left[\mathrm{~km}^{2}\right]$ にすればよいというルールに なっている. しかし実際の耕作面積は, 約 4,000

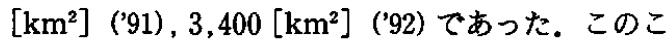
とは, ルールによると’91年はおおよそ涸渴危険率 $0.5, ' 92$ 年は 0.2 という極めて涸渴の可能性の高い作
付状況であったことになる.

b) EGATの作成したルール (Dry Season Area Reduction Curve)

図一 9 中央の右上がりの直線は, 夕イ電力省 （EGAT）の提案した作付制約ルールである.これ は，様々な直線の傾きや切片を試行錯誤法により， シミュレーションから求められたものであるが, こ のルールは現実の作付状況とはかけ離れて, 水位が 低い時にはかなり耕作面積を小さくしたルールと なっている。これはシミュレーションの期間中の貯 水量が涸渴に至らないようにした, つまり涸晹危険 率 $\beta$ を 0 にしたためである。 また発電量をも同時に 考虑しているために，耕作面積を小さくすることに より水位を高くとることを促し，なるべく多くの発 電量を得ることを期待したルールとなっている (EGAT, 1991).

\section{4. 作付区域の制限, 指亭及U統制}

'94年の場合は, 年初の時点の貯水量がすでに $85\left[\right.$ 億 $\left.\mathrm{m}^{3}\right]$ という極めて低水位で始まっており, 政 府としては米の乾期作をやめるように指導している。 しかし日本が米の輸入を一部認めたことにより米価 が高騰し ('93年の 2 倍)，農民としては米を作りた がっている状況である.米価が良いので, 樑さ $20[\mathrm{~m}]$ の井戸を堀り, 地下水をポンプで汲み上げて水を調 達し，それで乾期作を始めるところもあれば，雨期 が終わって農作物の収穫が済んだ後, 耕作地帯にま だ水があるときは,これから先の水のあてがなくて 
も，その水を使って乾期作を始めてしまうところも ある. 乾期が進んで耕作地帯に水がなくなってくる と，タイ王立潅覞局 (RID) に貯水池の水を放流する ことを要求し, 結局は放流を制限できなくなってし まう.よって貯水池が涸渴するのは必至の状況であ る.

ここで述ベたルールは, 乾期の始まる時点で残存 貯水量が少ない時に, 乾期潅溉耕作面積を制限する ことにより放流 (潅溉用水供給)を抑えて, 貯水池が 許容以上の確率で涸渴することを避けるというもの である. その制限をする際のガイドラインとなる ルールを提案するところまでが筆者らにできる限界 である．現実に耕作面積の制限を行うことができる かどうか,これまでの水利用慣行を統制していける かどうかは，夕イ王国政府の抱える大きな政策課題 である.

\section{V. おわクに}

本研究に際し, タイ王国電力省 (EGAT) 気象水文 部のKitti Naparaxawong, Sumate Chaiyapruk, Chutchawal Sawasdirurk, Boonsong Peetanonchaiの各氏にデータや資料の提供, ダム管理実態の 説明など多大な協力を頂いた．また文部省科学研究 費補助金, 国際学術研究, 平成 3-5 年 (課題番号 030416016 ：椎貝博美代表)の援助を得た。記して深甚 なる謝意を表する。

\section{参考文献}

1）吉川秀夫-竹内邦良（1975）：晹水持続曲線の性 質とその応用，土木学会論文報告集第234号， pp. 61-71

2 ）国際協力事業団 (1988): タイ国チャオピア川洪 水予報システム計画調査主報告書

3 ) 高谷好一 (1982): 熱帯デルタの農業発展ーメ ナム・デルタの研究一

4 ）竹内邦良・富田茂·伊藤幸義（1984）：給水用貯 水池のためのDDCルールカーブ, 第28回水理講 演会論文集, pp. 21-26

5 ) 竹内邦良・新谷 渡 (1993)：熱帯モンスーン域 に扔ける大規模貯水池操作のためのDDC・FDC ルールカーブ, 第37回水工学論文集, pp. 93-98

6) Electricity Generating Authority of Thailand (1989): Basic Data Existing Hydro Power Plants, EGAT, Thailand, Report No. 31104-3201, pp. 1-22
7) Electricity Generating Authority of Thailand (1991): Improvement of the Operating Rule Curves for Bhumibol and Sirikit Reservoirs, EGAT, Thailand, Reserch Report No. 60-57

8) ESCAP (1991): Assessment of Water Resources and Water Demand by User Sectors in Thailand, United Nation, New York

9) Kerdpitak, C. and J. Kaewkulya and V. Kao-Upathum and C. Khayankarnnavee (1987): Water Use, Post Impoundment Environmental Evaluation and Development Planning of the Bhumibol and Sirikit Projects, Vol. 6: Human Use Values, EGAT, Thailand, pp. 19-111

10) Kono, Y. (1993): Changing Features of Irrigated Agriculture in the Chao Phraya Delta, Thailand, Proc. Environmentally Sound Water Resources Utilization, Bangkok, Vol. II, pp. III-224-III-231

11) Mahasandana, T. (1989): Hydro Power Development in the Chao Phraya River Basin, EGAT, Hydro Power Engineering Department, Thailand

12) Panichpong, S. and S. Chomcharn (1987): Land Use, Post Impoundment Environmental Evaluation and Development Planning of the Bhumibol and Sirikit Projects, Vol. 6: Human Use Values, EGAT, Thailand, pp. 1-18

13) Peetanonchai, B. (1993): The Impact of Water Resources Development in the Upper Basin on the Inflow of the Downstream Reservoir, Thechnical Workshop on "Hydrological Research in a Changing Environment in Sub-Humid and Humid Tropical Area", pp. 1-21

14) Rohde, F.G. and K. Naparaxawong (1981): Modified Standard Operation Rules for Reservoirs, Journal of Hydrology, 51, pp. 169-177

15) Royal Irrigation Department (1912-88): "Thailand Hydrological Yearbook", Royal Irrigation Department, Hydology Division, Thailand, Vol. 1-31

16) Sribhibhadh, S. and C. Sawatdirurk (1988): 
Water Management of Multipurpose Projects in Thailand, Conflict Analysis in Reservoir Management, AIT, Thailand, pp. 349-370

17) Takeuchi, K. (1986): Chance Constraint Model for Real-Time Reservoir Operation Using Drought Duration Curve, Water Resources Research, Vol. 22, No. 4, pp. 551-558

18) Takeuchi, K. (1993): Analyses of Flow Regime of the Chao Phraya River, Proceed- ings of an international symposium, Hydrology of Warm Humid Regions, IAHS Publication No. 216, pp. 181-193

19) Tingsanchali, T. (1993): Water Resources Utilization in the Chao Phraya Basin with Minimum Water Shortage and Environmental Hazards, Proc. Environmentally Sound Water Resources Utilization, Bangkok, Vol. II, pp. III-32-III-42

（受付：1994年 7 月 4 日，受理：1994年 7 月27日） 